Research Paper

\title{
Effects of extracts of leaves from Sparattosperma leucanthum on hyperuricemia and gouty arthritis
}

\author{
Rita de Cássia Lemos Lima, Fernanda Cristina Ferrari, Maíra Ribeiro de Souza, \\ Bruna Maria de Sá Pereira, Carmen Aparecida de Paula, Dênia Antunes Saúde-Guimarães*
}

Laboratório de Plantas Medicinais, Escola de Farmácia, Universidade Federal de Ouro Preto, Campus Morro do Cruzeiro, s/n. Ouro Preto, Minas Gerais CEP 35400-000, Brazil

\section{A R T I C L E I N F O}

\section{Article history:}

Received 15 August 2014

Received in revised form

25 November 2014

Accepted 29 November 2014

Available online 8 December 2014

\section{Keywords:}

Sparattosperma leucanthum

Hyperuricemia

Xanthine oxidase

Gout

Inflammation

\begin{abstract}
A B S T R A C T
Ethnopharmacological relevance: The species Sparattosperma leucanthum (Vell.) K. Schum is used in Brazilian folk medicine to treat rheumatism, throat ulcers, stomatitis, syphilis, bladder stones and as blood cleanser. The aim of this study was to evaluate the potential, in vitro and in vivo, of the extracts of leaves from Sparattosperma leucanthum to treat hyperuricemia and inflammation in the gouty arthritis model.

Materials and methods: Ethyl acetate extract (SLE), methanolic extract (SLM) and aqueous extract (SLW) were evaluated in vitro on $\mathrm{XO}$ inhibitory activity and in vivo in an experimental model with oxonateinduced hyperuricemia in mice which was used to evaluate anti-hyperuricemic activity and liver xanthine oxidase (XOD) inhibition. Anti-inflammatory activity was also investigated on MSU crystalinduced paw edema model.

Results: Sparattosperma leucanthum crude extracts showed expressive results on urate-lowering activity in blood. SLW at the dose of $125 \mathrm{mg} / \mathrm{kg}$ has proved to be active in reducing hyperuricemia and was capable to inhibit the hepatic xanthine oxidase enzyme (XOD). SLM showed anti-hyperuricemic activity on all doses tested; however, this extract showed activity on the XOD only at the dose of $500 \mathrm{mg} / \mathrm{kg}$. SLE, at the three evaluated doses, has proved to be active in reducing hyperuricemia in vivo and was able to inhibit XO activity in vitro at the concentration of $100 \mu \mathrm{g} / \mathrm{mL}$. This extract was also able to inhibit XOD activity in vivo at the doses of $250 \mathrm{mg} / \mathrm{kg}$ and $500 \mathrm{mg} / \mathrm{kg}$. SLE (125 and $250 \mathrm{mg} / \mathrm{kg}$ ) and SLW (500 mg/kg) showed significant anti-inflammatory activity on monosodium urate crystal-induced paw edema model. Conclusions: The ethyl acetate, methanolic and aqueous extracts of Sparattosperma leucanthum showed significant results on evaluated models and therefore may be important agents for the treatment of gouty arthritis and hyperuricemia.
\end{abstract}

(c) 2015 Elsevier Ireland Ltd. All rights reserved.

\section{Introduction}

Hyperuricemia is characterized by an increase in uric acid blood levels due to a metabolic disorder on its production or on its excretion (Haidari et al., 2008). Uric acid is the last metabolite of the purine catabolic pathway in humans. Uric acid is formed by oxidation of hypoxanthine to xanthine and xanthine to uric acid by the enzyme xanthine oxidase (XO). Gouty arthritis is a worldwide disease which is intimately associated to hyperuricemia, whereas this disorder is characterized by precipitation of monosodium urate crystals in the joints leading to an intense inflammatory

\footnotetext{
* Corresponding author. Tel.: +55 3135591031.

E-mail addresses: saude@ef.ufop.br,

saudeguima@gmail.com (D.A. Saúde-Guimarães).
}

process and consequently, pain (Schumacher, 2008). The therapeutic approach against gout is given by the treatment of inflammation and the control of hyperuricemia. Nowadays, allopurinol is the only drug used on the control of hyperuricemia that acts by inhibiting hepatic xanthine oxidase enzyme (XOD) activity, then reducing serum uric acid levels. However, allopurinol is not an effective drug to treat acute gout attacks (Dubchak and Falasca, 2010) and its use has been associated with adverse effects, such as fever, skin rashes, allergic reactions, hepatitis and nephropathy (Umamaheswari et al., 2009). Nonsteroidal anti-inflammatory drugs such as indomethacin are frequently used in the first-line therapies for acute inflammation in gout; however these drug may develop serious side effects such as gastrointestinal toxicity, renal toxicity or gastrointestinal bleeding (Cronstein and Terkeltaub, 2006). Therefore, the search for new drugs with anti-inflammatory and urate-lowering activities, including xanthine oxidase 
inhibitors, has been the focus of several studies (Zhu et al., 2004; Mo et al., 2007; Ahmad et al., 2008; Haidari et al., 2008; Liu et al., 2008; Huang et al., 2011; Sabina et al., 2011; De Souza et al., 2012). Sparattosperma leucanthum (Vell.) K. Schum, popularly known as "cinco-chagas", "cinco-folhas" or "caroba-branca” (Correa, 19261978), is a species from Bignoniaceae family largely distributed in Atlantic forest, Amazon forest and Cerrado regions in Brazil (Lorenzi, 2002). Ethnobotanical studies relate the use of Sparattosperma leucanthum in Brazilian folk medicine as anti-rheumatic, anti-inflammatory, blood cleanser, in the treatment of throat ulcers, stomatitis, syphilis, skin rashes and bladder stones (Correa, 1926-1978; Patzlaff, 2007; Leite et al., 2008; Crepaldi and Peixoto, 2009; Costa and Leitão, 2011; Oliveira et al., 2011). Previous phytochemical studies about Sparattosperma leucanthum described the isolation of the flavone pinocembrin-7-O-(-d-neohesperidoside), a derivative of the flavone pinocembrin, which presents significant antioxidant activities (Costa and Leitão, 2011; Rasul et al., 2013). Recent studies have shown the relation between antioxidant and anti-inflammatory activities, which is given by inhibiting the action of ROS, NO and other free radicals that are involved with the inflammatory process, particularly on acute gout attacks (Busso and So, 2010). Therefore, the aim of this study was to evaluate, in vitro and in vivo, the xanthine oxidase inhibitory activity and the anti-hyperuricemic and anti-inflammatory activities in vivo of Sparattosperma leucanthum crude extracts.

\section{Material and methods}

\subsection{Chemicals}

Xanthine oxidase (EC 1.1.3.22) from cow's milk (1.3 units $/ \mathrm{mL}$ ), xanthine, potassium oxonate, allopurinol and indomethacin were purchased from Sigma-Aldrich. Uric acid assay kit was purchased from Bioclin (Minas Gerais - Brazil). Monosodium urate (MSU) crystals were prepared according to the previously described method (Rasool and Varalakshmi, 2006; Sabina et al., 2011). Methanol, ethyl acetate, hexane, dimethilsulfoxide (DMSO) and Tween 80 were of analytical grade.

\subsection{Plant material}

Leaves from Sparattosperma leucanthum (Vell.) K. Schum were collected in Minas Gerais, Brazil, in March, 2011, with permission of Instituto Chico Mendes de Conservação da Biodiversidade ICMBio/Sistema de Autorização e Informação em BiodiversidadeSISBIO (license no. 17021-5). A voucher specimen (OUPR 28217) is deposited at the herbarium of Instituto de Ciências Exatas e Biológicas - UFOP, Ouro Preto, Brazil.

\subsection{Preparation of plant extracts}

The leaves were dried in an air circulating oven at $37^{\circ} \mathrm{C}$ for two weeks, and pulverized. Part of the obtained powder $(1.2 \mathrm{~kg})$ was exhaustively extracted with each solvent used, by percolation, at room temperature. The plant material was first extracted with hexane until exhaustion of the vegetable material with this solvent. After, it was exhaustively extracted with ethyl acetate and finally with methanol. The solvents were removed under reduced pressure, at $40{ }^{\circ} \mathrm{C}$, in order to obtain dried crude hexanic extract (SLH, $40.8 \mathrm{~g}$ ), $130.6 \mathrm{~g}$ of dried crude ethyl acetate extract (SLE) and dried crude methanolic extract (SLM, 90.0 g). The aqueous extract was obtained by exhaustive extraction of $72.0 \mathrm{~g}$ of powder plant material with distillated water, by percolation, and then, the water was removed by lyophilization, yielding $12.1 \mathrm{~g}$ of dried crude aqueous extract (SLW).

\subsection{Physical and chemical color reaction and TLC analysis}

The physical and chemical color reactions were performed with the extracts as previously described (Farnsworth, 1966; MariniBetollo et al., 1981; Wagner et al., 1984; Matos, 1997). The flavonoids were identified by hydrochloric acid-magnesium reaction and TLC sprayed with NP/PEG reagent. Anthocyanins and catechins were assayed using hydrochloric acid and sodium hydroxide. Tannins were analyzed using ferric trichloride and potassium ferrocyanide. The presence of saponins was evaluated using froth test and the Lieberman-Burchard reaction. Coumarins, quinones and anthraquinones were identified by alkali reaction. The presence of triterpenes and steroids were assayed using the Lieberman-Burchard reaction. Alcaloids were analyzed by the Dragendorff reaction. Analyzes were carried out using thin layer chromatography and colorimetric pharmacognostic tests.

\subsection{Evaluation of in vitro xanthine oxidase (XO) inhibition activity of SLE, SLM and SLW}

The assay with crude extracts of Sparattosperma leucanthum was carried out using a previous methodology described by Ferraz-Filha et al. (2006), with modifications. For extracts with an inhibitory activity of more than $25 \%$ at $100 \mu \mathrm{g} / \mathrm{mL}$, the $\mathrm{IC}_{50}$ values were determined. These assays were realized with extract concentrations from 10 at $100 \mu \mathrm{g} / \mathrm{mL}$, in triplicate. Thus, inhibition percentages are the mean of triplicate observations.

Initially, $6.4 \mathrm{mg}$ of crude extracts (SLE, SLM and SLW) was solubilized in $100 \mu \mathrm{L}$ of DMSO and then diluted with water, yielding a $640 \mu \mathrm{g} / \mathrm{mL}$ solution of each extract. Thereafter, $500 \mu \mathrm{L}$ of each solution was added in $1.3 \mathrm{~mL}$ of phosphate buffer $65 \mathrm{mM}$ ( $\mathrm{pH} 7.4$ ) containing $0.28 \mathrm{U} / \mathrm{mL}$ of $\mathrm{XO}$ and incubated for $10 \mathrm{~min}$ at $30{ }^{\circ} \mathrm{C}$ in order to promote the interaction between the compounds of the extracts and XO enzyme. After the incubation period, $1.4 \mathrm{~mL}$ of substrate xanthine $(0.6 \mathrm{mM})$ was added into the test solution. The absorbance of each sample was measured, spectrophotometrically (Varian BIO-50), at every minute for $10 \mathrm{~min}$ in a wavelength of $295 \mathrm{~nm}$. Allopurinol (positive control) was tested in the same conditions than the crude extracts, at a final concentration of $10 \mu \mathrm{g} / \mathrm{mL}$. XO inhibitory activity was expressed as the percentage inhibition of XO in the above assay mixture system, calculated as: $\%$ inhibition $=(1-$ test inclination/blank inclination $) \times 100$.

\subsection{Animals}

Male albino Swiss mice (25-30 g) were supplied by Universidade Federal de Ouro Preto. Animals were divided into experimental groups $(n=6)$, housed in plastic cages and maintained on a 12-h light/12-h dark cycle. They were given standard chow and water ad libitum. All experimental procedures were approved by the Ethical Committee of Universidade Federal de Ouro Preto, Brazil (no. 2012/65).

\subsection{Preparation of drugs and test solutions for in vivo methods}

Allopurinol solution, test solutions and potassium oxonate suspension were prepared according to the medium weight of each group. Allopurinol, SLE and SLM were solubilized in DMSO: Tween 80:water (1:1:8) (vehicle) and SLW was dissolved in water. Potassium oxonate was prepared in suspension with $\mathrm{NaCl} 0.9 \%$ solution. Indomethacin was also dissolved in vehicle to the final concentration of $1 \mathrm{mg} / \mathrm{mL}$. Monosodium urate (MSU) crystals were suspended in $0.9 \%$ sterile saline $(40 \mathrm{mg} / \mathrm{mL}$ ) immediately before its use. 


\subsection{Anti-hyperuricemic effects in oxonate-induced hyperuricemic mice and inhibition of liver XOD activity}

In order to evaluate the anti-hyperuricemic activity of Sparattosperma leucanthum extracts, an experimental model of hyperuricemia induced by potassium oxonate was adopted according to De Souza et al. (2012), with modifications. Animals were divided into 12 experimental groups $(n=6)$ and fasted $2 \mathrm{~h}$ before drug administration. Potassium oxonate, an uricase inhibitor, was administrated to the animals of groups $2-12$ (250 mg/kg, I.P.) in the first and third days of the experiment. Oral treatments were given by gavage, $1 \mathrm{~h}$ after the potassium oxonate administration, once a day, for 3 days of experiment. Experimental group 1 (normal control group) and group 2 (hyperuricemic control group) received only vehicle by oral route. Group 3 was treated with allopurinol (10 mg/kg, P.O.). Experimental groups 4-12 were treated with SLE, SLM and SLW, at the doses of 125, 250 and $500 \mathrm{mg} / \mathrm{kg}$, once a day, for 3 experimental days. At the third day, animals were anesthetized with an association of ketamine and xylasine (100 and $20 \mathrm{mg} / \mathrm{kg}$, respectively), intraperitoneally, $1 \mathrm{~h}$ after final drug administration, in order to collect the blood from abdominal aorta. Blood samples were maintained at room temperature until blood coagulation and then centrifuged at $1500 \mathrm{~g}$ for $5 \mathrm{~min}$. Supernatant were collected and centrifuged at $3000 \mathrm{~g}$ for 10 min until complete sera separation. These materials were stored at $-20{ }^{\circ} \mathrm{C}$ until uric acid quantification. Mice livers were also collected, washed in $0.9 \%$ cold saline solution and stored at $-80{ }^{\circ} \mathrm{C}$ until XOD activity determination.

\subsubsection{Uric acid assay}

An enzymatic-colorimetric method, using a standard diagnostic kit (Bioclin, Brazil), according to manufacturer's instructions, was used in order to evaluate serum uric acid concentration.

\subsubsection{Assays inhibition of liver XOD activity}

The residual activity of XOD was spectrophotometrically determined monitoring uric acid formation from xanthine, as previously described by De Souza et al. (2012), with modifications. Initially, mice livers were homogenized in $5 \mathrm{~mL}$ of $80 \mathrm{mM}$ sodium phosphate buffer ( $\mathrm{pH}$ 7.4). The homogenates were centrifuged at $3000 \mathrm{~g}$ for $10 \mathrm{~min}$ at $4{ }^{\circ} \mathrm{C}$. Then, the lipidic layer was removed and the supernatant was centrifuged at $10,000 \mathrm{~g}$ for $60 \mathrm{~min}$ at $4{ }^{\circ} \mathrm{C}$. The supernatant obtained was used in the XOD residual activity test and protein dosing. In test tubes containing $100 \mu \mathrm{L}$ of liver homogenate and $5.4 \mathrm{~mL}$ of potassium oxonate solution $(1 \mathrm{mM})$ in50 mM sodium phosphate buffer ( $\mathrm{pH}$ 7.4) previously incubated at $35^{\circ} \mathrm{C}$ for $15 \mathrm{~min}$ was added $1.2 \mathrm{~mL}$ of xanthine solution $(250 \mathrm{mM})$. The reaction was stopped after 0 and $30 \mathrm{~min}$ by adding $0.15 \mathrm{~mL}$ of $0.6 \mathrm{M} \mathrm{HCl}$. Thereafter, test tubes were centrifuged at $3000 \mathrm{~g}$ for $5 \mathrm{~min}$ and the absorbance of supernatant was measured at $295 \mathrm{~nm}$ using a Varian 50Bio UV/VIS spectrophotometer. Total protein concentration was determined spectrophotometrically according to Bradford (1976). XOD activity was expressed as nanomoles of uric acid formed per minute per milligram protein.

\subsection{Effects of SLE, SLM and SLW of Sparattosperma leucanthum on gouty arthritis inflammation model}

In order to evaluate the anti-inflammatory activity of Sparattosperma leucanthum crude extracts on gout, an experimental model, previously described by De Souza et al. (2012), was carried out with modifications.

The assay was carried out in a period of three days. The animals were divided into 12 experimental groups $(n=6)$. On the first day of the experiment, the inflammation was induced by intradermal injection of $0.1 \mathrm{~mL}$ ( $4 \mathrm{mg}$ ) of MSU suspension into the mice right hind paw in all animals of groups $2-12$. Animals of normal control group (group 1 ) received $0.1 \mathrm{~mL}$ of $0.9 \%$ sterile saline solution by intradermal injection into the right hind paw and were orally treated with vehicle, once a day, during the 3 days of experiments. Animals of group 2 were also treated with vehicle and were used as MSU-induced control group. Group 3 (positive control) was orally treated with indomethacin $(3 \mathrm{mg} / \mathrm{kg})$. Animals of groups 4-12 were treated by oral route with SLE, SLM and SLW, at the doses of 125,250 and $500 \mathrm{mg} / \mathrm{kg}$. Treatments were administered on the first experimental day, $1 \mathrm{~h}$ before MSU injection, and repeated daily for 2 more days.

Paw thickness was measured with a caliper rule $(150 \mathrm{~mm}-6$ in. Vonder, China) at $4 \mathrm{~h}, 24 \mathrm{~h}, 48 \mathrm{~h}$ and $72 \mathrm{~h}$ after MSU injection and inflammatory swelling was expressed as thickness variation $(\Delta)$.

\subsection{Statistical analysis}

In the in vitro evaluation of $\mathrm{XO}$ inhibition activity, the $\mathrm{IC}_{50}$ was obtained for extracts which presented an activity above $25.0 \%$ using GraphPad Prism 5.1 Software (Inc., San Diego, CA, U.S.A.). The $\mathrm{IC}_{50}$ values of the extracts were calculated from regression lines of a plot of \% inhibition versus extract concentration. These assays were realized with extract concentrations from 10 at $100 \mu \mathrm{g} / \mathrm{mL}$.

Experimental data were analyzed using GraphPad Prism 5.1 Software and results were presented as mean values \pm S.E.M. The statistical evaluation of results from hyperuricemic and MSU crystal-induced paw edema assays was analyzed utilizing Oneway variance analysis (ANOVA), followed by Newman-Keul's test. $P$ values $\leq 0.05$ were considered statistically significant.

\section{Results}

\subsection{Physical and chemical color reactions and TLC}

Preliminary phytochemical analyses are important methodologies for prediction of groups of secondary metabolites present in plants. Therefore, analyses were performed to detect classes of secondary metabolites in extracts of Sparattosperma leucanthum. In SLE were detected flavonoids (aglycone), anthraquinones/quinones, triterpenes and steroids. In SLM were identified tannins, flavonoids (glycosides and aglycone) and anthraquinones glycosides. In SLW were detected tannins, flavonoids glycosides, anthraquinones glycosides, coumarins and saponins.

\subsection{In vitro xanthine oxidase inhibitory activity}

The positive control, allopurinol, a known xanthine oxidase inhibitor, showed an inhibition of $95.63 \%$ at the concentration of $10 \mu \mathrm{g} / \mathrm{mL}$ and $\mathrm{IC}_{50}$ of $0.328 \mu \mathrm{g} / \mathrm{mL}$. The ethyl acetate crude extract (SLE) showed an inhibition of $46.0 \%$ and $\mathrm{IC}_{50}$ of $107.0 \mu \mathrm{g} / \mathrm{mL}$. The methanolic (SLM) and aqueous (SLW) crude extracts showed inhibitions of $23.50 \%$ and $13.10 \%$, respectively, as shown in Table 1.

\section{Table 1}

In vitro inhibitory xanthine oxidase activity of crude extracts of Sparattosperma leucanthum.

\begin{tabular}{lcll}
\hline Test solution & Concentration $(\mu \mathrm{g} / \mathrm{mL})$ & Inhibition $(\% \pm$ S.D. $)$ & $\mathrm{IC}_{50}(\mu \mathrm{g} / \mathrm{mL})$ \\
\hline Allopurinol & 10 & 95.63 & 0.328 \\
SLE & 100 & $46.00 \pm 0.223$ & 107.00 \\
SLM & 100 & $23.50 \pm 0.248$ & - \\
SLW & 100 & $13.10 \pm 0.370$ & - \\
\hline
\end{tabular}




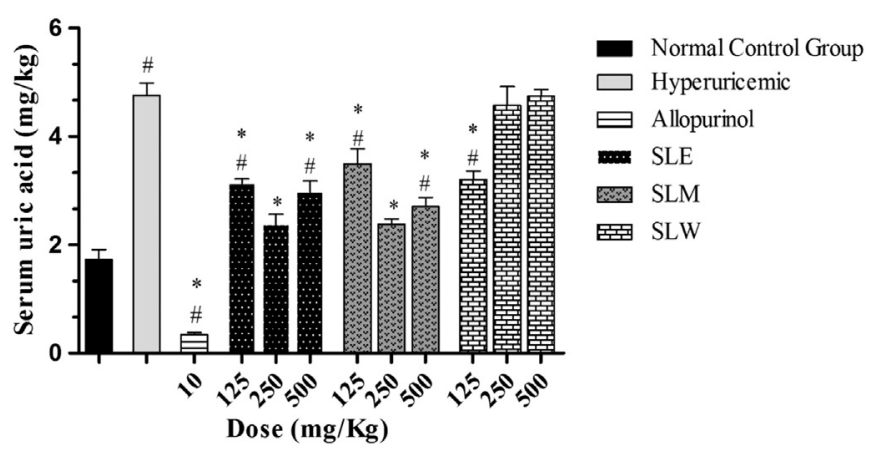

Fig. 1. Anti-hyperuricemic effects of Sparattosperma leucanthum ethyl acetate extract (SLE), methanolic extract (SLM) and aqueous extract (SLW) in mice pretreated with potassium oxonate. Experiments were performed as described in Section 2. Data present mean \pm S.E.M. $(n=6)$. One-way ANOVA followed by Newman-Keul's test was used for statistical significance. ${ }^{*} P<0.001$ compared with hyperuricemic control group; ${ }^{\#} P<0.001$ compared to normal control group.

Table 2

Effects of Sparattosperma leucanthum ethyl acetate extract (SLE), methanolic extract (SLM) and aqueous extract (SLW) on xanthine oxidase activity in mice liver in vivo.

\begin{tabular}{llll}
\hline Treatment & $\begin{array}{l}\text { Dose }(\mathrm{mg} / \\
\mathrm{kg})\end{array}$ & $\begin{array}{l}\text { XOD activity }(\mathrm{U} / \mathrm{mg} \\
\text { protein })\end{array}$ & $\begin{array}{l}\text { Inhibition } \\
(\%)\end{array}$ \\
\hline $\begin{array}{l}\text { Control Normal } \\
\text { Hyperuricemic }\end{array}$ & - & $15.70 \pm 1.376$ & - \\
$\quad-$ & $16.18 \pm 0.686$ & - \\
control & & $4.180 \pm 0.219^{* * *}$ & 74.16 \\
SLE & 10 & $13.47 \pm 1.883$ & 16.75 \\
& 125 & $10.50 \pm 0.566^{*}$ & 35.10 \\
SLM & 250 & $10.14 \pm 0.638^{*}$ & 37.33 \\
& 500 & $14.90 \pm 1.937$ & 7.91 \\
SLW & 125 & $14.34 \pm 1.710$ & 11.37 \\
& 250 & $10.86 \pm 0.707^{*}$ & 32.88 \\
& 500 & $10.68 \pm 1.035^{*}$ & 34.00 \\
& 125 & $16.36 \pm 0.275$ & - \\
\hline
\end{tabular}

Data represent mean \pm S.E.M. $(n=6)$. One-way ANOVA followed by Newman-Keul's test was used for statistical significance.

$U=$ nanomole uric acid $/ \mathrm{min}$.

$* P<0.05$, compared to hyperuricemic control group.

** $P<0.001$, compared to hyperuricemic control group.

\subsection{Effects of SLE, SLM and SLW on serum urate levels in hyperuricemic mice}

Potasium oxonate solution was able to significantly increase serum urate levels compared to normal control group (Fig. 1). Allopurinol $(10 \mathrm{mg} / \mathrm{kg}$ ) promoted a significant reduction on serum urate levels of hyperuricemic mice to values lower than that found in normal animals. Treatments with SLE and SLM were able to significantly reduce serum urate levels compared to hyperuricemic control group in the three doses evaluated. SLW significantly reduced serum urate levels at $125 \mathrm{mg} / \mathrm{kg}$.

\subsection{Effects of SLE, SLM and SLW on XOD activity in mice liver}

SLE significantly inhibited liver XOD activity at the doses of 250 and $500 \mathrm{mg} / \mathrm{kg}$ by $35.10 \%$ and $37.33 \%$, respectively (Table 2). SLM was able to inhibit XOD activity at $500 \mathrm{mg} / \mathrm{kg}$ by $32.88 \%$. SLW, at $125 \mathrm{mg} / \mathrm{kg}$, inhibited XOD activity by $34.00 \%$ when compared to hyperuricemic control group. Allopurinol inhibited XOD activity by $74.16 \%$

\subsection{Effects of SLE, SLM and SLW on monosodium urate crystal- induced inflammation in mice}

MSU crystals injection induced a significant increase in paw thickness when compared to negative control (Fig. 2). Paw edema was found to be reduced in mice treated with SLE at $250 \mathrm{mg} / \mathrm{kg}$ at $4 \mathrm{~h}, 24 \mathrm{~h}$ and $72 \mathrm{~h}$. SLM was not able to reduce significantly paw edema in any of the doses tested. SLW was able to reduce significantly paw edema at $500 \mathrm{mg} / \mathrm{kg}$ at $72 \mathrm{~h}$. Indomethacin ( $3 \mathrm{mg} / \mathrm{kg}$ ) has also shown a significant anti-inflammatory activity.

\section{Discussion}

Uric acid is the last metabolite of the purine catabolic pathway in humans (Dröge, 2002). In some pathologic conditions, the organism loses the ability to eliminate uric acid and, consequently, an increase in its levels can lead to the precipitation of monosodium urate crystals in the joints, which, in turn, causes gouty arthritis or gout (Chiang et al., 1994; Busso and So, 2010).

Allopurinol is one of the main drugs used to treat and control hyperuricemia. This drug presents an effective inhibitory activity of xanthine oxidase, but its use can cause several adverse effects to patients, and these damages are reported as the main cause of abandonment of anti-hyperuricemia therapy (Umamaheswari et al., 2009). As nowadays, none of the clinically available medicines can be used to treat both hyperuricemia and the inflammatory process that occurs in gouty arthritis (Ahmad et al., 2008) and facing the need to new therapeutics options to treat gout and its consequences, the present study aimed to evaluate antihyperuricemic and anti-inflammatory activities of Sparattosperma leucanthum leaves extracts, as well as elucidate their possible action pathways in experimental models in vivo.

SLW was effective on reducing uric acid levels and inhibiting XOD activity, which indicates that this extract may accomplish its antihyperuricemic effect mainly through this action mechanism. SLE was able to reduce uric acid levels at three evaluated doses, and significantly inhibited liver XOD activity at 250 and $500 \mathrm{mg} / \mathrm{kg}$. Besides showed an inhibition in vitro of XOD activity indicating that this extract can contain substances with different potencial to inhibit the XOD activity. SLM significantly reduced serum uric acid levels at all doses tested; however, it did not show XOD inhibitory activity, which indicates that this extract may accomplish its anti-hyperuricemic effect mainly through other action mechanisms.

The experiment using MSU crystal-induced inflammation has been used to simulate acute attacks of gout occur due to urate crystals accumulation in the joints, which promotes the beginning of a chain of inflammatory reactions such those related to synovial cells activation (especially leukocytes) leading to acute inflammation and promoting tissue damaging (Rasool and Valarakshmi, 2006; Martinon et al., 2006). In MSU crystal-induced inflammation, SLE showed significant results in paw edema reduction at $250 \mathrm{mg} / \mathrm{kg}$, at $4 \mathrm{~h}, 24 \mathrm{~h}, 48 \mathrm{~h}$ and $72 \mathrm{~h}$. These results can be considered promising, since SLE also presented significant antihyperuricemic and liver XOD inhibitory activities at the same dose in hyperuricemic mice.

The detection of flavonoids, triterpene and steroids in SLE, flavonoids glycosides in SLM and flavonoids glycosides and saponins in SLW indicate that this secondary metabolites may be responsible for anti-hyperuricemic and anti-inflammatory effects of the extracts, since there are previous reports of such activities for these compounds (Fang et al., 2005; Chen et al., 2006, 2011; Mo et al., 2007; Nguyen and Nguyen, 2013; Nkanwen et al., 2013; Wu et al., 2014). However, additional studies are required to isolate and identify the bioactive substances present in SLE, SLM and SLW. 


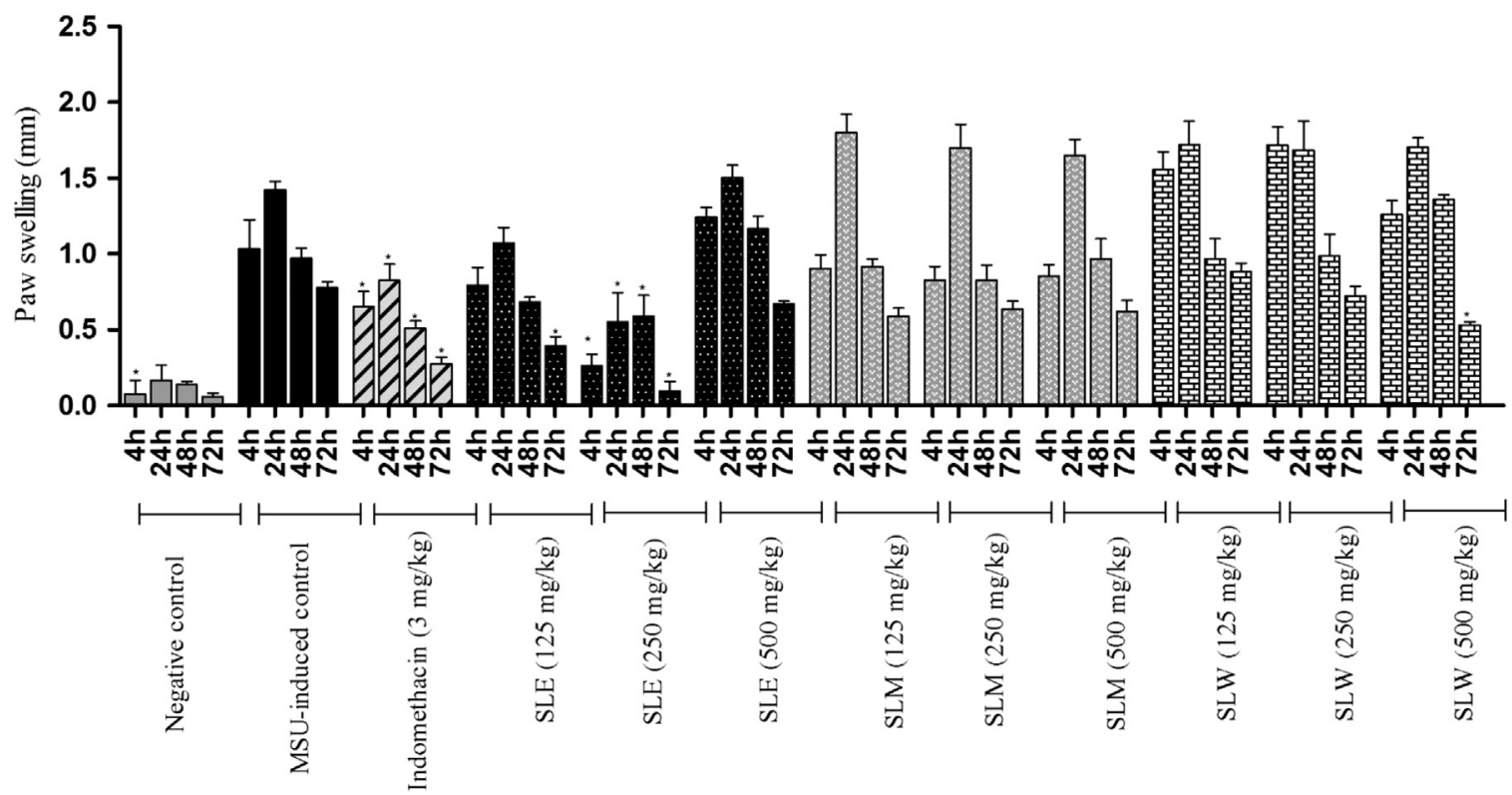

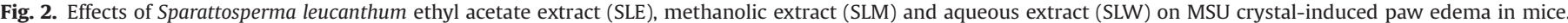

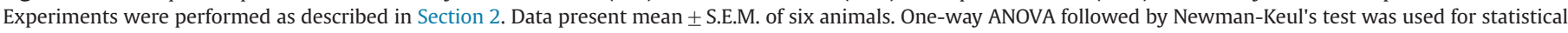
significance. ${ }^{*} P<0.001$ compared with paw swelling after MSU crystals injection in vehicle-treated mice.

\section{Conclusion}

Sparattosperma leucanthum ethyl acetate extract was efficient in reducing hyperuricemia and MSU crystal-induced inflammation, as well as in inhibiting the in vitro and in vivo xanthine oxidase activity, which indicates that this extract may accomplish its effects mainly through liver XOD inhibition. Aqueous extract, at $125 \mathrm{mg} / \mathrm{kg}$, showed significant anti-hyperuricemic activity and was able to inhibit XOD, which is very important, since in folk medicine Sparattosperma leucanthum is used as tea. Methanol extract was able to reduce serum urate levels in hyperuricemic mice; however its activity could be given by a different pathway, which gives a very important characteristic to Sparattosperma leucanthum. Flavonoids, saponins, triterpene and steroids, detected in extracts, may be the bioactive constituents. Therefore, Sparattosperma leucanthum extracts are promising agents for the treatment of hyperuricemia and gouty arthritis since they possess both anti-hiperuricemic and anti-inflammatory properties.

\section{Acknowledgments}

The authors would like to thank FAPEMIG, REDE TOXIFAR/ FAPEMIG - CBB - RED-00008-14 (Rede Mineira de Ensaios Toxicológicos e Farmacológicos/ Fundação de Amparo à Pesquisa de Minas Gerais); CAPES (Coordenação de Aperfeiçoamento de Pessoal de Ensino Superior), CNPq (Conselho Nacional de Pesquisa), Brazil companies, and UFOP (Universidade Federal de Ouro Preto), Brazil for financial support.

\section{References}

Ahmad, N.S., Farman, M., Najmi, M.H., Mian, K.B., Hasan, A., 2008. Pharmacological basis for use of Pistacia integerrima leaves in hyperuricemia and gout. Journal of Ethnopharmacology 117, 478-482.

Bradford, M., 1976. A rapid and sensitive method for the quantitation of microgram quantities of protein utilizing the principle of protein-dye binding. Analytical Biochemistry 72, 248-254.

Busso, N., So, A., 2010. Mechanisms of inflammation in gout. Arthritis Research \& Therapy 12 (206), $1-8$.
Chen, G.L., Wei, W., Xu, S.Y., 2006. Effect and mechanism of total saponin of Dioscorea on animal experimental hyperuricemia. The American Journal of Chinese Medicine 34 (1), 77-85.

Chen, L., Yin, H., Lan, Z., Ma, S., Zhang, C., Yang, Z., Li, P., Lin, B., 2011. Antihyperuricemic and nephroprotective effects of Smilax china L. Journal of Ethnopharmacology 135, 399-405.

Chiang, H.C., Lo, Y.J. Lu, F.J. 1994. Xanthine oxidase inhibitors from leaves of Alsophila spinulosa (Hook) Tryon. Journal of Enzyme Inhibitions 8, 61-71.

Correa, M.P., 1926-1978. Dicionário de plantas úteis do Brasil e das exóticas cultivadas, 6. Imprensa Nacional: Instituto Brasileiro de Desenvolvimento Floresta, Rio de Janeiro.

Costa, F.N., Leitão, G.G., 2011. Evaluation of different solvent systems for the isolation of Sparattosperma leucanthum flavonoids by counter-current chromatography. Journal of Chromatography A 1218, 6200-6205.

Crepaldi, M.O.S., Peixoto, A.L., 2009. Use and knowledge of plants by "Quilombolas" as subsidies for conservation efforts in an area of Atlantic Forest in Espírito Santo State, Brazil. Biodiversity and Conservation 19, 37-60.

Cronstein, B.N., Terkeltaub, R., 2006. The inflammatory process of gout and its treatment. Arthritis Research \& Therapy 8, 1-7.

De Souza, M.R., Paula, C.A., Resende, M.L.P., Grabe-Guimarães, A., Filho, J.D.S. Saúde-Guimarães, D.A., 2012. Pharmacological basis for use of Lychnophora trichocarpha in gouty arthritis: anti-hyperuricemic and anti-inflammatory effects of its extract, fraction and constituents. Journal of Ethnopharmacology $142,845-850$.

Dröge, W., 2002. Free radicals in the physiological control of cell function Physiology Reviews 82, 47-95.

Dubchak, N., Falasca, G.F., 2010. New and improved strategies for the treatment of gout. International Journal of Nephrology and Renovascular Disease 3, 145-166.

Fang, S.H., Rao, Y.K., Tzeng, Y.M., 2005. Inhibitory effects of flavonol glycosides from Cinnamomum osmophloeum on inflammatory mediators in LPS/IFN- $\gamma$-activated murinemacrophages. Bioorganic \& Medicinal Chemistry 13, 2381-2388.

Farnsworth, N.R., 1966. Biological and phytochemical screening of plants. Journal of Pharmaceutical Science 55, 225.

Ferraz-Filha, Z.S., Vitolo, I.F., Fietto, L.G., Lombardi, J.A., Saúde-Guimarães, D.A., 2006. Xanthine oxidase inhibitory activity of Lychnophora species from Brazil ("Arnica”). Journal of Ethnopharmacology 107, 79-82.

Haidari, F., Rashidi, M.R., Keshavarz, S.A., et al., 2008. Effects of onion on serum uric acid levels and hepatic xanthine dehydrogenase/xanthine oxidase activities in hyperuricemic rats. Pakistan Journal of Biological Sciences 11, 1779-1784.

Huang, J., Wang, S., Zhu, M., Chen, J., Zhu, X., 2011. Effects of genistein, apigenin, quercetin, rutin and astilbin on serum uric acid levels and xanthine oxidase activities in normal and hyperuricemic mice. Food and Chemical Toxicology 49, 1943-1947.

Leite, J.P.V., Fernandes, J.M., Fávaro, L.B., Gontijo, D.C., Marotta, C.P.B., Siqueira, L.C. Maia, R.T., Garcia, F.C.P., 2008. Plantas medicinais no entorno do Parque Estadual da Serra do Bigadeiro. MG Biota 1, 16-32.

Liu, X. Chen, R., Shang, Y., Jiao, B., Huang, C.,2008. Lithospermic acid as a novel xanthine oxidase inhibitor has anti-inflammatory and hypouricemic effects in rats. Chemico-Biological Interactions 176, 137-142.

Lorenzi, H., 2002. Árvores brasileiras: manual de identificação de cultivo de plantas arbóreas do Brasil, fourth ed. Instituto Plantarum, Nova Odessa. 
Marini-Betollo, G.B., Nicoletti, M., Patamia, M., 1981. Plant screening by chemical and chromatographic procedure under field conditions. Journal of Chromatography 218, 113-217.

Martinon, F., Pétrilli, V., Mayor, A., Tardivel, A., Tschopp, J., 2006. Gout-associated uric acid crystals activate the NALP3 inflammasome. Nature 440, 237-241.

Matos, F.J.A., 1997. Introdução à Fitoquímica Experimental. Edições UFC, Fortaleza p. 141.

Mo, S.F., Zhou, F., Lv, Y.Z., Hu, Q.H., Zhang, D.M., Kong, L.D., 2007. Hyporuricemic action of selected flavonoids in mice: structure-activity relationships. Biological \& Pharmaceutical Bulletin 30, 1551-1556.

Nkanwen, E.R.S., Gojayev, A.S., Wabo, H.K., Bankeu, J.J.K., Iqbal, M.C., Guliyev, A.A., Tane, P., 2013. Lanostane-type triterpenoid and steroid from the stem bark of Klainedoxa gabonensis. Fitoterapia 86, 108-114.

Nguyen, M.T.T., Nguyen, N.T., 2013. A new lupine triterpene from Tetracera scandens L., xanthine oxidase inhibitor. Natural Products Research 27 (1), 61-67.

Oliveira, L.S., Muzitano, M.F., Coutinho, M.A.S., Melo, G.O., Costa, S.S., 2011. Plantas medicinais como recurso terapêutico em comunidade do entorno da reserva biológica do tinguá, RJ, Brasil - metabólitos secundários e aspectos farmacológicos. Inter Science Place 17, 54-74.

Patzlaff, R.G., 2007. Estudo Etnobotânico de Plantas de uso Medicinal e Místico na Comunidade de Capoeira Grande, Pedra de Guaratiba, Rio de Janeiro, RJ, Brasil (Dissertation). Instituto de Pesquisas Jardim Botânico do Rio de Janeiro, Escola Nacional de Botânica Tropical p. 124.
Rasool, M., Varalakshmi, P., 2006. Supressive effect of Withania somnifera root powder on experimental gouty arthritis: an in vivo and in vitro study. ChemicoBiological Interactions 164, 174-180.

Rasul, A., Millimouno, F.M., Eltayb, W.A., Ali, M., Li, J., Li, X., 2013. Pinocembrin: a novel natural compound with versatile pharmacological and biological activities. BioMed Research International 2013, 1-9.

Sabina, E.P., Nagar, S., Rasool, M., 2011. A role of piperine on monosodium urate crystal-induced inflammation - an experimental model of gouty arthritis. Inflammation 34, 184-192.

Schumacher, H.R., 2008. The pathogenesis of gout. Cleveland Clinical Journal of Medicine 75, S2-S4.

Umamaheswari, M., Asokkumar, K., Sivashanmugam, A.T., Remyaraju, A., Subhadradevi, V., Ravi, T.K., 2009. In vitro xanthine oxidase inhibitory activity of the fractions of Erythrina stricta Roxb. Journal of Ethnopharmacology 124, 646-648.

Wagner, H., Bladt, S., Zgainsky, E.M., 1984. Plant Drug Analysis: A Thin Layer Chromatography Atlas. Springer Verlag, Berlin p. 320.

Wu, X.H., Ruan, J.L., Zhang, J., Wang, S.Q., Zhang, Y.W., 2014. Pallidifloside D, a saponine glycoside constituent from Smilax riparia, resist to hyperuricemia based on URAT1 and GLUT9 in hyperuricemic mice. Journal of Ethnopharmacology 157, 201-205.

Zhu, J.X., Wang, Y., Kong, L.D., Yang, C., Zhang, X., 2004. Effects of Biota orientalis extract and its flavonoid constituents, quercetina and rutin on serum uric acid levels in oxonate-induced mice and xanthine dehydrogenase and xanthine oxidase activities in mouse liver. Journal of Ethnopharmacology 93, 133-140. 